
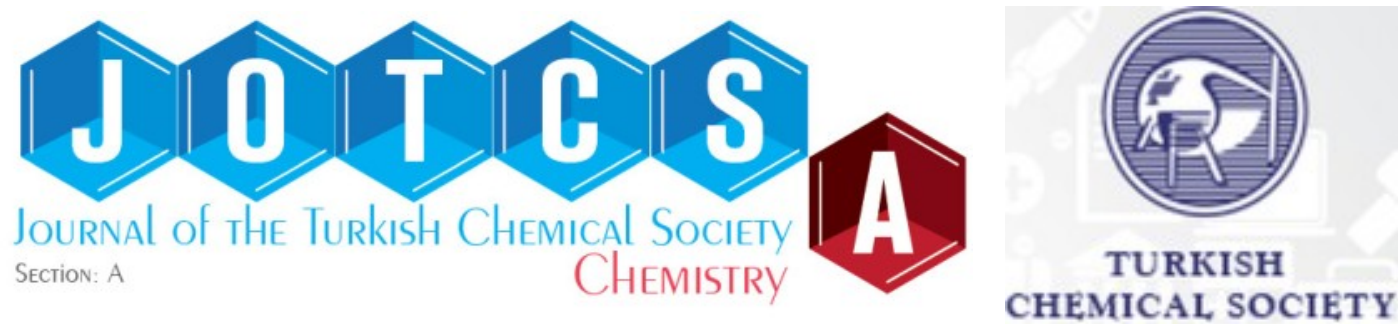

\title{
Copper Oxide Nanoparticles: Synthesis, Characterization, Antimicrobial Activities and Catalytic Reduction of Methylene Blue
}

\author{
Selda Doğan Çalhan ${ }^{*} \square D$, Mustafa Gündoğan² $\square$ \\ $1^{*}$ Mersin University, Faculty of Pharmacy, Department of Pharmaceutical Biotechnology, 33169 \\ Mersin, Turkey. \\ ${ }^{2}$ Mersin University, Faculty of Pharmacy, Department of Pharmaceutical Technology,33169 Mersin, \\ Turkey.
}

Abstract: In recent years, metal nanoparticles have been applied in many areas due to their attractive properties. Copper oxide nanoparticles, in particular, have drawn much attention owing to their electrical, catalytic, optical, antibacterial, and antifungal properties. In this study, copper oxide nanoparticles were synthesized using Onosma Sericeum Willd (Boraginaceae) extract with a simple, economical, and eco-friendly method for the first time. The synthesized nanoparticles were characterized using ultraviolet-visible spectrophotometry, field emission scanning electron microscopy, and X-ray diffraction. The particle size distribution and zeta potential measurements of the copper oxide nanoparticles were measured with the dynamic light scattering technique. It was determined that the copper oxide nanoparticles with a particle size of less than $100 \mathrm{~nm}$ showed a catalytic effect in the reduction of methylene blue (MB). At room temperature, up to $90 \%$ MB dye degradation was achieved. Also, the antimicrobial properties of the copper oxide nanoparticles were investigated in this study. The results of the study showed that synthesized copper oxide nanoparticles could be used as a promising agent in nanotechnology applications.

Keywords: Copper oxide nanoparticles, Onosma Sericum Willd, Green synthesis, Catalysis, Antibacterial activity

Received: November 26, 2019. Accepted: May 19, 2020.

Cite this: Doğan Çalhan S, Gündoğan M. Copper Oxide Nanoparticles: Synthesis, Characterization, Antimicrobial Activities and Catalytic Reduction of Methylene Blue. JOTCSA. 2020;7(2):561-70.

DOI: https://doi.org/10.18596/jotcsa.650993.

*Corresponding author. E-mail: seldadgn@gmail.com, seldadgn@mersin.edu.tr

\section{INTRODUCTION}

Metal nanoparticles are used in various fields due to properties including high surface area/volume ratio, differences in chemical reactivity and catalytic properties, and selective drug delivery to target organs and tissues with easy surface modification. They can be used in electrochemical processes and hydrogen production, electronic devices and communication systems, sensor design, and biomedical and medical imaging technologies. They also have the potential to be used in many different fields, including material chemistry $(1,2)$.

Copper oxide nanoparticles (CuONPs) attract attention with their catalysis (3), sensor (4), and superconducting applications (5) due to their superior physicochemical properties. These structures are also considered to be semiconductor materials with photocatalytic (6) 
and photovoltaic (7) properties. Some studies have shown that CuONPs can be antibacterial agents (8) and used in the treatment of cancer (9).

CuONPs can be synthesized by different chemical methods such as chemical reduction (10), microwave radiation (11), and thermal decomposition (12). However, synthesis procedures performed with these methods involve the adsorption of toxic chemicals to the surface. It can cause serious side effects, especially in medical applications. The use of toxic chemicals, which pose a risk to the environment and human health, in chemical methods has led researchers to develop new alternative methods. Green chemistry (13), which is defined as the utilization of a dozen principles that prevent or reduce the emergence and use of substances that pose a danger to the environment and human health in the design, production, and use of chemical products, is an alternative approach that has been extensively researched in recent years. Association of green chemical principles with nanotechnology has been shown by Schmidt (2006) as the key to a sustainable society in the 21 st century (14). The high toxicity and long biocompatibility of nanoparticle technologies, which have been known for a long time, have urged scientists to develop new synthetic procedures that are more secure, environmentally friendly, and producing as little waste as possible, using natural and renewable raw materials that can be easily integrated into biomedical applications. With this new green nanotechnology approach, it has become much easier to find solutions to the problems caused by the conventional synthesis procedure.

Green nanotechnology has been reported to use plants and extracts such as Aloe vera, Azadirachta indica (linden), Camellia sinensis (tea), Jatropha curcas (castor nuts), Acalypha indica (castor nettle), Cymbopogon sp (lemongrass) being preferred in metal nanoparticle synthesis as they are cheap and renewable natural resources. Also, microorganisms such as Rhodococcus sp., Sargassum wightii, Pseudomonas stutzeri, Candida glabrata, M13 bacteriophage, Fusarium oxysporum, and Thermomonospora sp. are extensively used in the synthesis of metal nanoparticles as natural resources that serve the purpose of green synthesis $(15,16)$. Particularly in CuONP synthesis, the leaves and stems of the Gundelia tournefortii (kenger) plant (17), the leaves of the Psidium guajava plant (18), lemon juice (19) and the Gloriosa superba L plant (20) are used.

Plants do not require any other agents in the production of metal nanoparticles because of the phenolic species they contain (21). Therefore, in recent years, studies on plants and plant extracts and nanoparticle synthesis have been conducted with increasing acceleration. Onosma sericeum Willd is a member of the Boraginaceae family and has been known for its wound healing properties for many years among people in Adıyaman, Turkey. The Boraginaceae family, found in tropical, subtropical, and temperate regions of the world, is represented by 154 genera and 2500 species (22).

Depending on the chemical composition and ionic features, several classes of dye molecules have been reported. Thiazine dyes such as MB are aromatic, organic, and toxic pollutants (23). Methylene blue, like the other organic dyes, are released by different industries such as cosmetic, textile, pharmaceutical, and plastic industries (24). There are findings in the literature that $\mathrm{MB}$ affects the central nervous system (25). Besides, this pollutant can be accumulated in soil and water and threaten human health. Therefore the investigation of catalytic degradation is essential. In recent years nanoparticles have been used in the degradation of the dye. Especially owing to their large surface area, CuONPs showed very high reactivity.

In this study, CuONP synthesis was carried out by using the root extract of the Onosma Sericeum Willd plant fort the first time, the wound healing properties of which are wellknown, and applying a completely green method without the need for any other organic solvents or stabilizing agents. The characterization of the CuONPs was elucidated using analytical methods. The antimicrobial activities of the obtained CuONPs against a range of Gram-positive and Gram-negative bacteria were evaluated. Its catalytic activity on the reduction of methylene blue, a harmful pollutant for the environment, in the presence of CuONPs was also studied.

\section{MATERIALS AND METHODS}

\section{Materials}

Copper(II) nitrate $\left(\mathrm{Cu}\left(\mathrm{NO}_{3}\right)_{2}, 99 \%\right)$, methylene blue $\left(\mathrm{C}_{16} \mathrm{H}_{18} \mathrm{CIN} \mathrm{N}_{3} \mathrm{~S}, 95 \%\right)$, sodium borohydride $\left(\mathrm{NaBH}_{4}, 99 \%\right)$ were obtained from Sigma. Gram-positive bacterial strains Staphylococcus 
aureus (ATCC25925) and Bacillus subtilis (ATCC 6633), gram-negative bacterial strains Escherichia coli (ATCC25923), Acinetobacter baumannii (ATCCS 02026) and Aeromonas hydrophila (ATCC95080) were purchased from the Refik Saydam Hıfzıssıhha Institute, Ankara, Turkey. All the chemicals used in the study were of analytical grade, and $18.2 \mathrm{~m} \Omega$ of distilled water needed throughout the research was obtained through the Milli-Q A10 water purification system.

\section{Instruments}

All spectrophotometric measurements were conducted by using the Shimadzu UV-1800 spectrophotometer. The structural morphology of the CuONPs was obtained using a Zeiss / Supra 55 Field Emission Scanning Electron Microscope (FE-SEM). The XRD of the nanoparticles was studied by a high-resolution Rigaku SmartLab brand X-ray diffractometer (XRD). The size distribution of the CuONPs and zeta potential measurements were performed using a Zetasizer Nano-ZS (Malvern Instruments).

\section{Preparation of Extract}

The Onosma Sericeum Willd plant was collected from the Adıyaman-Besni region in Turkey between April and July 2018. The identification of the plant species was made by Assoc. Prof. Dr. Riza Binzet of the Faculty of Arts and Sciences at Mersin University. The collected plant samples were first cleaned from dust and impurities using tap water, followed by distilled water. The plant was left to dry in a clean and dry place. The root portions of the plant were extracted for the CuONP synthesis. For the extraction, $200 \mathrm{~mL}$ of distilled water was added to $20 \mathrm{~g}$ of roots that were cut into small pieces and subjected to maceration for 6 hours at a temperature that did not exceed $90{ }^{\circ} \mathrm{C}$ in a shaking water bath. The extract was filtered in vacuo and stored in a refrigerator. Great care was taken to keep the extract as fresh as possible.

\section{Synthesis of the CuONPs}

Copper(II) nitrate $\left(\mathrm{Cu}\left(\mathrm{NO}_{3}\right)_{2}\right.$, Sigma) was used as the copper source. $5 \mathrm{~mL}$ of the extract (20 $\mathrm{g} / 200 \mathrm{~mL}$ ) dropwise was added to the $\mathrm{Cu}\left(\mathrm{NO}_{3}\right)_{2}$ solution $(25 \mathrm{~mL})$, which was prepared in $100 \mathrm{mM}$ and mixed in the magnetic stirrer. Next, $1000 \mu \mathrm{L}$ of $\mathrm{NaOH}(0.1 \mathrm{M})$ was added to the mixture.

The gray-green color that developed within half an hour indicated the synthesis of CuONP. The resulting CuONPs were separated by centrifugation $(10,000 \mathrm{rpm}, 20 \mathrm{~min})$, washed three times with deionized water, and dried in an oven at $80^{\circ} \mathrm{C}$ for 12 hours. The oven-dried sample was heat-treated in an ash oven at 400 ${ }^{\circ} \mathrm{C}$ for 3 hours (Figure 1 ). The obtained samples were stored in a cool and dry environment until analysis.

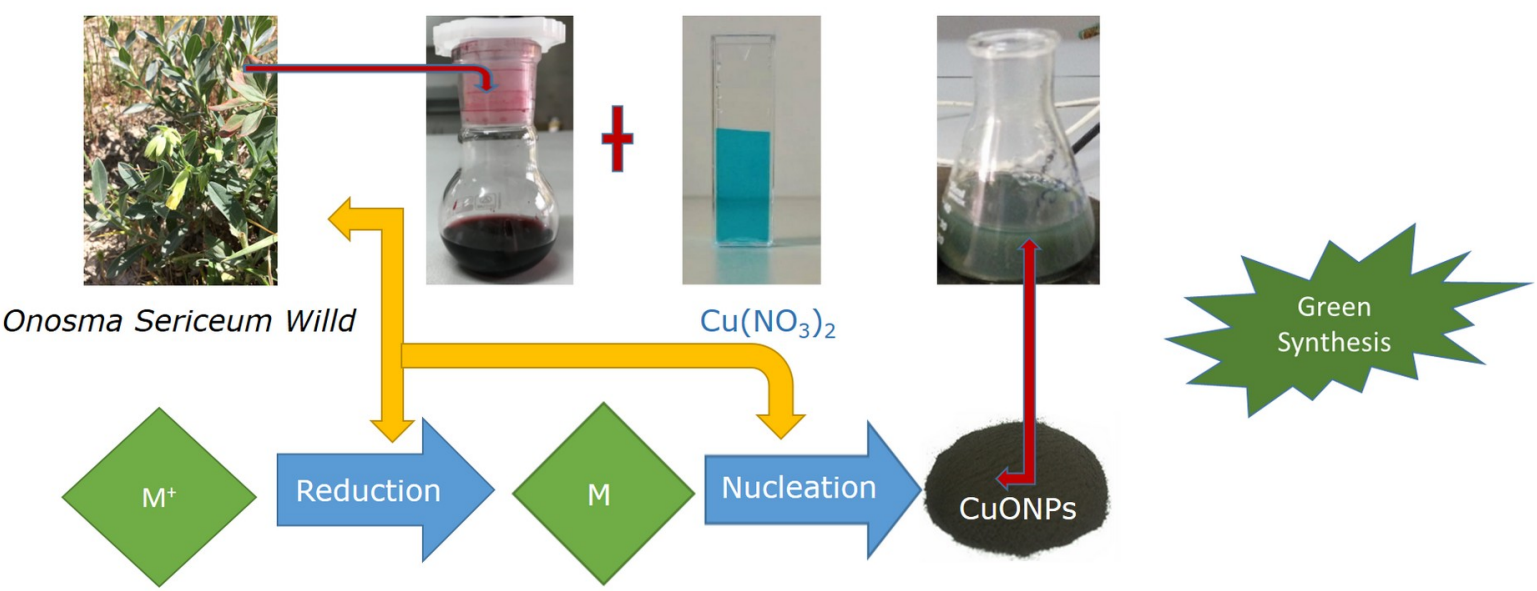

Figure 1. Schematic showing the synthesis procedure and mechanism of CuONPs

\section{Characterization of the Synthesized CuONPs}

The optical properties of the synthesized CuONPs were determined by an ultravioletvisible (UV-Vis) absorption spectrophotometer. All measurements were performed in the range of 200-800 nm, in quartz tubes and with
Shimadzu brand UV-1800 spectrophotometer adjusted to $1 \mathrm{~nm}$ resolution. The structural morphology of the CuONPs was obtained using a Zeiss / Supra 55 Field Emission Scanning Electron Microscope (FE-SEM). A high vacuum sputter platinum coating device was used for sample preparation. The crystal structure of the 
nanoparticles was illuminated by a highresolution Rigaku SmartLab brand x-ray diffractometer (XRD) using $\mathrm{Cu}(\mathrm{Ka})$ radiation (wavelength: $1.54 \AA$ ) operated at $40 \mathrm{kV}$ and 40 $\mathrm{mA}$ at room temperature. The size distribution of the CuONPs and zeta potential measurements were performed using a Zetasizer Nano-ZS [Malvern Instruments]. Before size distribution and zeta potential measurements, CuONPs were suspended in deionized water at a concentration of $1 \mathrm{mg} / 10$ $\mathrm{mL}$ and then sonicated using a sonicator at room temperature for $20 \mathrm{~min}$ at $40 \mathrm{~W}$ form a homogeneous suspension.

\section{Catalytic Properties}

$A$ reduction of $M B$ was observed in the presence of $\mathrm{NaBH}_{4}$ and CuONPs catalysis. $10 \mathrm{~mL}$ of water, $1 \mathrm{~mL}$ of $10 \mathrm{mM} 4 \mathrm{MB}$, and $1 \mathrm{~mL}$ of $1 \mathrm{mM}$ $\mathrm{NaBH}_{4}$ were mixed in a tube at $25{ }^{\circ} \mathrm{C}$. Then, 1 $\mathrm{mL}$ of $0.01 \%$ CuONPs solution was added to this mixture. Samples were taken from the obtained mixture at intervals of one minute, and measurements were made between 200-800 $\mathrm{nm}$ by UV-Vis region absorption spectrophotometer, and reaction monitoring was performed. Also, MB degradation (\%) was calculated using the following equation.

Dye degradation $(\%)=\left(\frac{C_{0}-C_{t}}{C_{0}}\right) \times 100$

$\mathrm{C}_{0}$ : Initial concentration of $\mathrm{MB}$

$\mathrm{C}_{\mathrm{t}}$ : Concentration of the dye solution after 45 minute

All dye concentrations were measured by UVVis absorption spectrophotometer. Results were given as the average of the three measurements.

\section{Antibacterial Activity}

In vitro antibacterial activity studies were performed against Staphylococcus aureus (ATCC 25925), Escherichia coli (ATCC 25923), Acinetobacter baumannii (ATCC 02026), Bacillus subtilis (ATCC 6633) and Aeromonas hydrophila (ATCC 95080) bacteria using the resazurin microplate method (resazurin microtitre assay-REMA) (26). Ampicillin was used as the standard drug in these studies. The color change of resazurin from blue to pink or colorless was considered positive and, therefore, an indication of bacterial growth. The minimum inhibition concentration (MIC) value was determined as the lowest concentration that prevents the resazurin from blue to pink or colorless. All antibacterial activity assays were repeated three times.

\section{RESULTS AND DISCUSSION}

\section{UV-Vis Analysis}

UV-Vis spectra were taken to evaluate the optical properties of the CuONPs obtained by biosynthesis. It was observed that the solutions of CuONPs obtained in $1 \mathrm{mg} / 10 \mathrm{~mL}$ water gave characteristic plasmon band at approximately $220 \mathrm{~nm}$ at room temperature. Surface plasmon absorbance due to the collective oscillation of the free conduction band electrons was very sensitive to determine CuONPs, which was in good agreement with previous works $(27,28)$. Figure 2 shows the UV-Vis spectra of the CuONPs and plant extract.

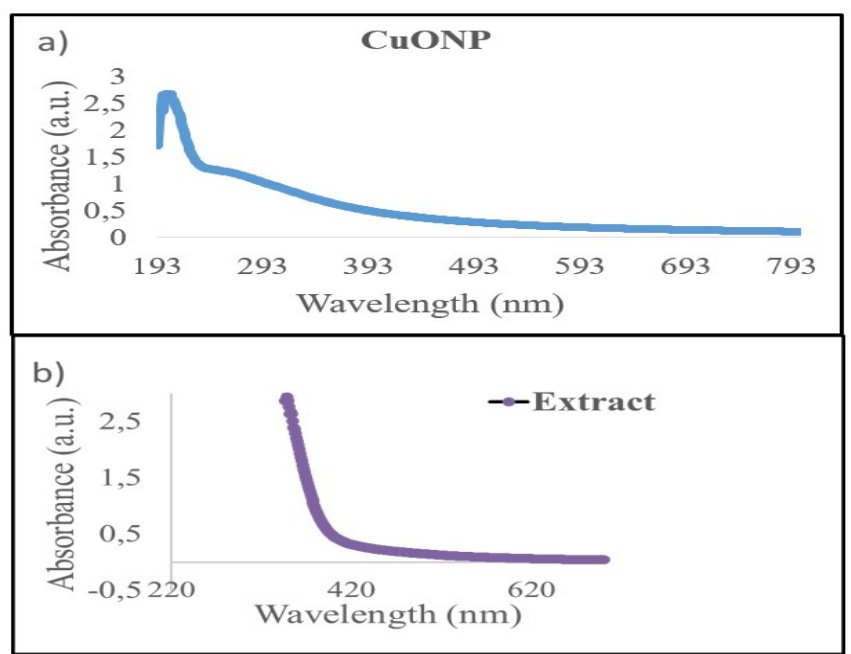

Figure 2. UV-Vis spectra a) CuONPs b) Extract of Onosma Sericeum Willd. 
FESEM Image and Particle Size Distribution FE-SEM analyses were performed to determine the surface morphology and particle size of the obtained CuONPs. The FE-SEM images showed that the CuONPs were spherical and approximately $70 \mathrm{~nm}$ in size. The dynamic light scattering (DLS) analysis results for size distribution were also in support of the FE-SEM results (Figure 3 ). The particle size was ranging from $70 \pm 6 \mathrm{~nm}$ in DLS measurements, which is an excellent agreement to FESEM particle size. DLS results were calculated by taking the average of the three measurements and standard deviation.

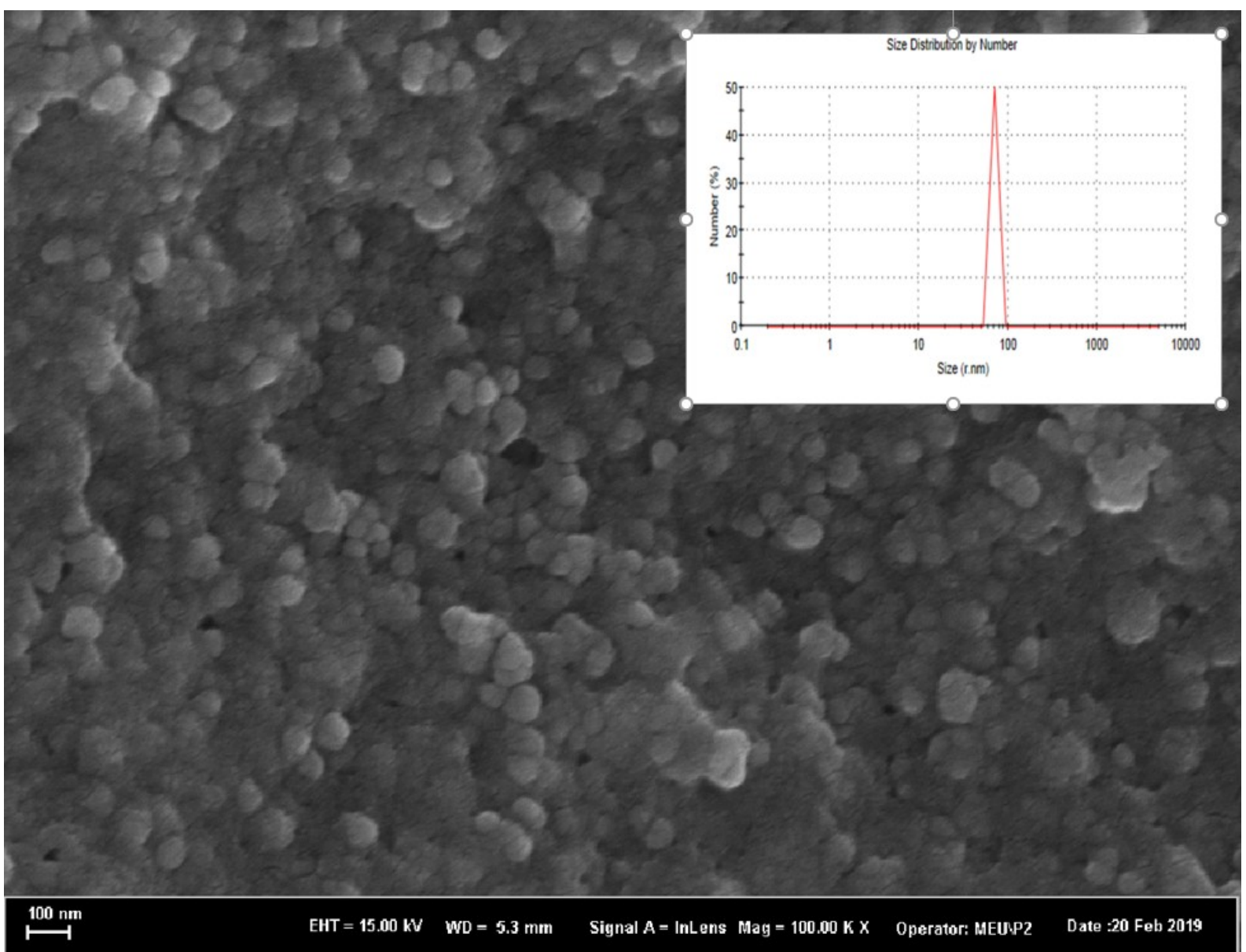

Figure 3. FESEM image and particle size distribution of CuONPs.

\section{Zeta Potential Measurements}

Zeta potential is an important parameter related to the stability of nanoparticles. The negative value of the zeta potential reveals that the CuONP negatively charged growths are coated and that electrostatic interaction between these nanoparticles may be responsible for the long-term stability of metal nanoparticles by preventing possible aggregation (28). In this study, the biomolecules present in the Onosma Sericeum Willd plant as inducing and stabilizing agents are thought to be responsible for the electrostatic interaction between the species. The zeta potential ( $\zeta$-Pot, $\mathrm{mV}$ ) for the CuONPs was measured as $-13.7 \pm 1.55$ at $25 \circ \mathrm{C}$ (Figure 4). Zeta potential results were calculated by taking the average of the three measurements and standard deviation. 
Zeta Potential Distribution

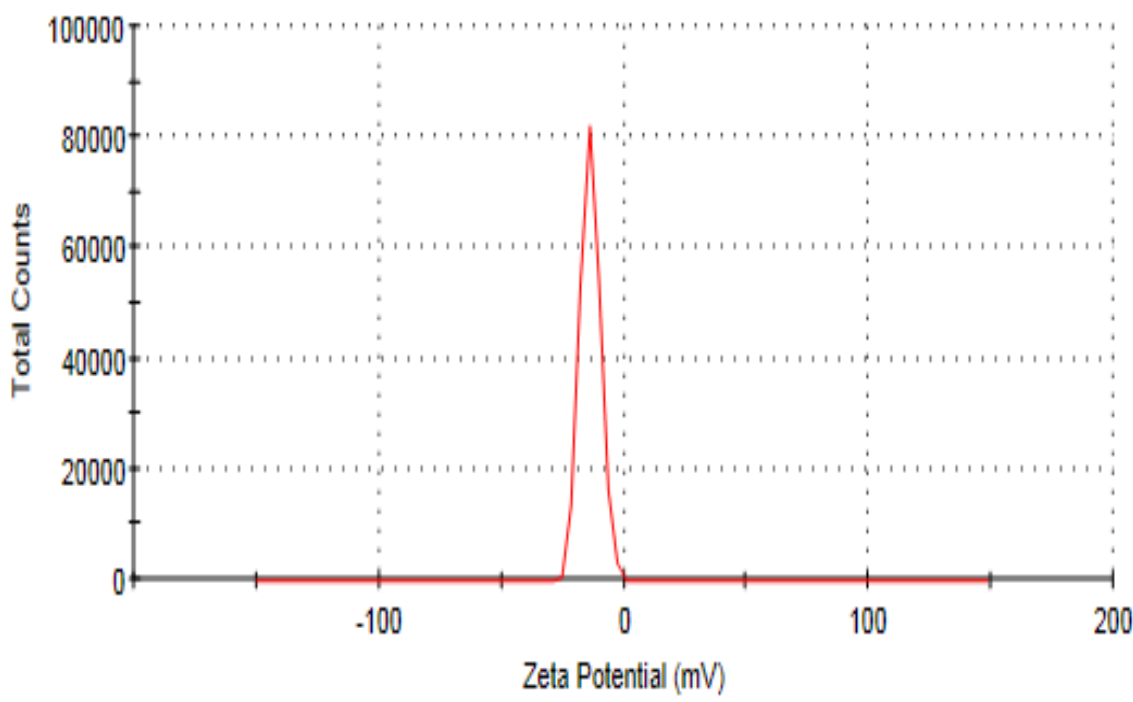

Figure 4. Zeta potential of CuONPs.

\section{XRD Analysis}

The powder X-ray diffraction technique was used to illuminate the CuONPs crystal structures obtained by biosynthesis. The diffraction patterns of XRD analyses, which were conducted to clarify the crystal structures, led to peaks observed at (111), (200), (202), (020), (202), (113), (311), (220) and (400).
These peaks confirmed the presence of CuONPs. The obtained XRD patterns were found to match those in the database of the Powder Diffraction Standards Joint Committee (JCPDS) file no: 89-7102. The information obtained was in agreement with the literature (29). The XRD spectrum obtained for the CuONPs is as shown in Figure 5.

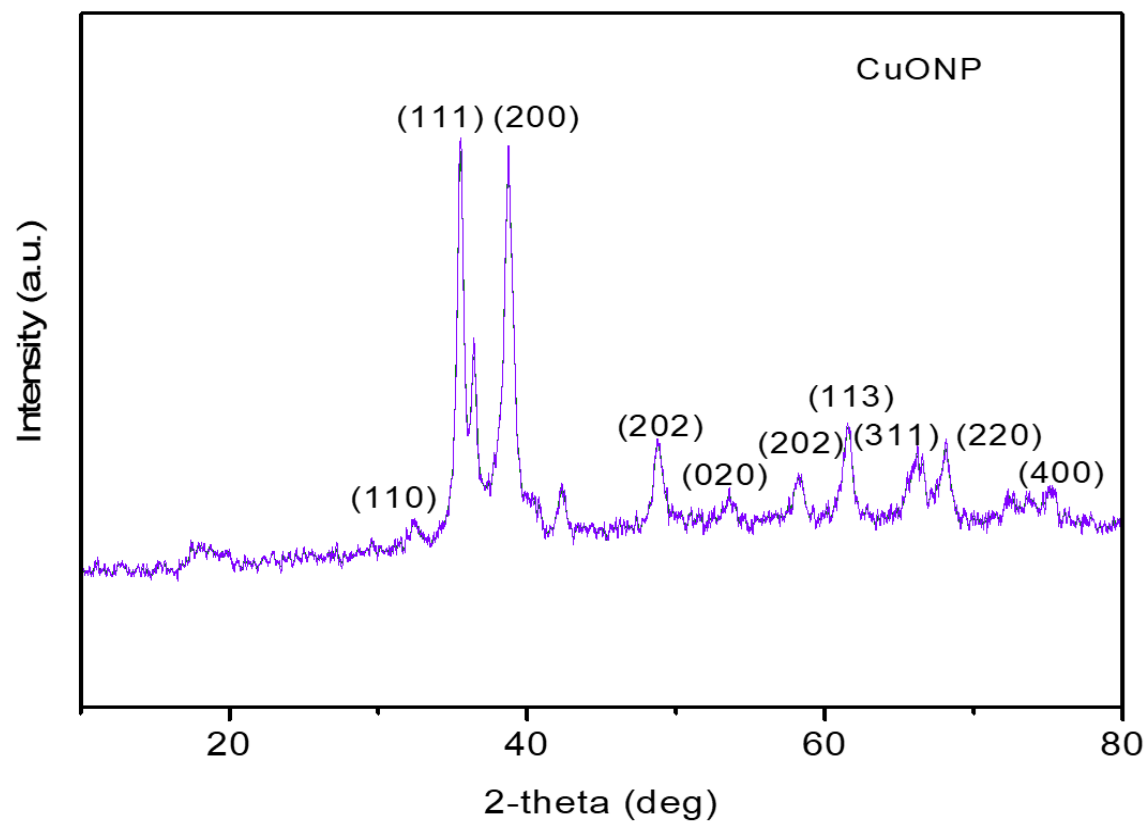

Figure 5. XRD spectra of CuONPs. 


\section{Catalytic Activities}

As described in catalytic properties, it was found that four characteristic peaks of MB at $246,292,613,664 \mathrm{~nm}$ changed only slightly before the addition of CuONPs. However, after adding $0.01 \%$ CuONPs solution to the same mixture, the absorbances were reread at specific intervals. In the first 45 minutes, the characteristic blue color of MB was significantly reduced, and the absorbance intensity decreased (Figure 6).

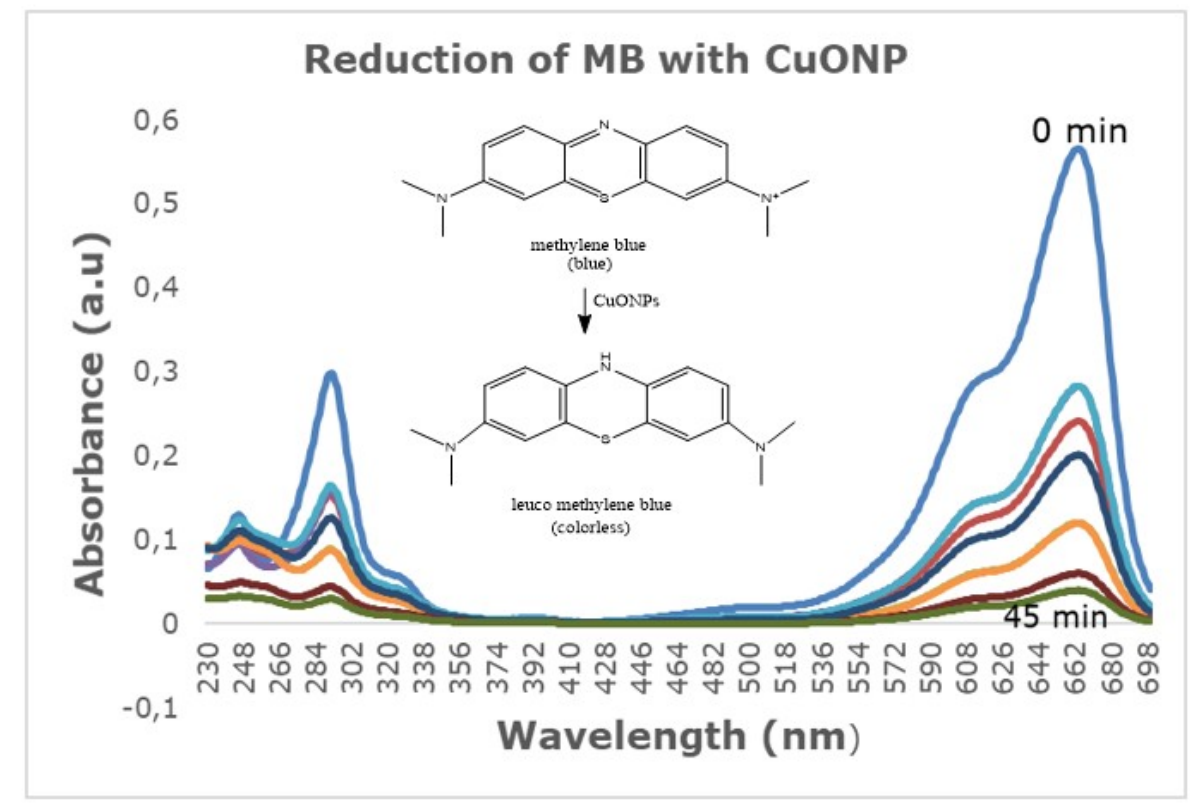

Figure 6. Reduction of MB with CuONP.

As a result of calculations, according to Equation 1, the rate of removal of $>90 \%$ observed in 45 minutes. Schematic representation of degradation mechanism MB to leuco-methylene blue is given in Figure 7 .<smiles>CN(C)c1ccc2nc3ccc(=[N+](C)C)cc-3sc2c1</smiles>

Methylene blue (Blue)

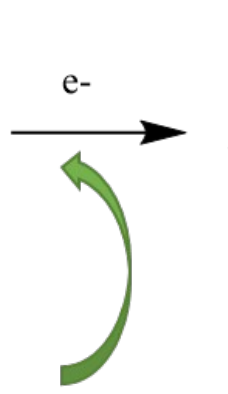

CuONPs<smiles>CN(C)c1ccc2c(c1)Sc1cc(N(C)C)ccc1N2</smiles>

Leucomethylene blue (Colorless)

Figure 7. Schematic representation of degradation MB to leuco methylene blue.

MB is a heterocyclic aromatic industrial pollutant-dye, which can be reduced to leucomethylene blue in the presence of $\mathrm{NaBH}_{4}$, but the reduction rate is prolonged. In this study forty-five minutes after the addition of the CuONPs to the dye, the absorbance is gradually decreased. The results show that CuONPs contribute to electron transfer, which plays an essential role in the reduction of methylene blue to leuco methylene blue. These results are in agreement with the late studies on catalytic degradation of MB using biosynthesized CuONPs (29).

\section{Antibacterial Activity}

The results obtained by determining antibacterial activity using the resazurin microplate method are summarized in Table 1. The CuONPs showed antibacterial activity at a concentration of $250 \mu \mathrm{g} / \mathrm{mL}$ for Bacillus 
subtilis (ATCC 6633), $500 \mu \mathrm{g} \mathrm{/} \mathrm{mL}$ for Staphylococcus aureus (ATCC 25925), Escherichia coli (ATCC 25923) and Aeromonas hydrophila (ATCC 95080) and $500 \mu \mathrm{g} / \mathrm{mL}$ for Acinetobacter baumannii (ATCC 02026). The results determined that the CuONPs showed lower antibacterial activity against the standard drug Ampicillin. However, the increase of
CuONPs concentration also increases the antibacterial effect. It is due to the direct interaction between CuONPs and the external membrane surface of the bacteria (30). However, since high concentrations can cause toxic effects in vivo, these effects should be investigated in further studies.

Table 1. The MIC values $(\mu \mathrm{g} / \mathrm{mL})$ of CuONP against the bacteria.

\begin{tabular}{llllll}
\hline $\begin{array}{l}\text { Copper oxide } \\
\text { Nanoparticle }\end{array}$ & $\begin{array}{l}\text { Staphylococcus } \\
\text { aureus } \\
\text { (ATCC 25925) }\end{array}$ & $\begin{array}{l}\text { Escherichia } \\
\text { coli } \\
\text { (ATCC25923) }\end{array}$ & $\begin{array}{l}\text { Acinetobacter } \\
\text { baumannii } \\
\text { (ATCC 02026) }\end{array}$ & $\begin{array}{l}\text { Bacillus } \\
\text { subtilis } \\
\text { (ATCC }\end{array}$ & $\begin{array}{l}\text { Aeromydrophila } \\
\text { hydCC } \\
\text { (ATCC }\end{array}$ \\
CuONP & 500 & 500 & $>500$ & $6633)$ & $95080)$ \\
Ampicillin & $31.25 \mu \mathrm{g} / \mathrm{mL}$ & $15.62 \mu \mathrm{g} / \mathrm{mL}$ & $125 \mu \mathrm{g} / \mathrm{mL}$ & $0.9 \mu \mathrm{gg} / 31.25$ \\
& & & & $\mathrm{~mL}$ & $\mu \mathrm{mg} / \mathrm{mL}$ \\
\hline
\end{tabular}

\section{CONCLUSION}

In this study, CuONPs were successfully prepared using the extract of Onosma Sericeum Willd (Boraginaceae) in a simple, economical, and environmentally friendly way. The synthetic process was advantageous to other conventional methods because this process did not require any organic solvent or toxic reagents. The synthesized nanoparticles were characterized by UV-Vis spectrophotometer, FESEM, and XRD. The particle size distribution and zeta potential measurements of the CuONPs were determined by the DLS method. The obtained CuONPs were found to have a spherical structure and an average particle size of $70 \mathrm{~nm}$. The synthesized CuONPs showed antimicrobial activity against Staphylococcus aureus (ATCC 25925), Escherichia coli (ATCC25923), Acinetobacter baumannii (ATCC 02026), Bacillus subtilis (ATCC 6633), Aeromonas hydrophila (ATCC 95080) at high concentration. The toxic effect of CuONPs, which increased antibacterial activity following the increase in the dose of CuONP, should be investigated in the future for in vivo studies. It also showed that the CuONPs performed excellently in the catalytic reduction of methylene blue. At room temperature, up to $90 \%$ MB dye degradation was achieved. In conclusion, it can be said that these nanostructures are candidate molecules for biomedical and biotechnological applications.

\section{FUNDING}

This study was funded by the Mersin University Scientific Research Project Unit with the Project No 2019-1-AP2-3412.

\section{ACKNOWLEDGEMENTS}

The authors would like to thank Assoc. Prof. Dr. Riza Binzet of the Faculty of Arts and Sciences at Mersin University for identifying the Onosma Sericeum Willd species, the Mersin University Advanced Technology, Training, Research and Application Center (MEITAM) for providing access to their laboratory facilities and Dr. Mahmut Ulger of the Department of Microbiology, Faculty of Pharmacy at Mersin University for determining the antibacterial results. The non-extended version of this paper was presented as oral presentation at the " 5 th International Turkic World Conference on Chemical Sciences and Technologies (ITWCCST 2019)" which will take place in Sakarya, Turkey between 25-29 October 2019.

\section{REFERENCES}

1. Castro L, Blázquez ML, Muñoz JÁ, González FG and Ballester A. Mechanism and applications of metal nanoparticles prepared by Bio-Mediated process. RASE. 2014; 3:1-18.

2. Feldheim DL, and Foss CA. Metal nanoparticles synthesis, characterization and applications. Marcel Dekker Inc; 2002.

3. Avgouropoulos G, Papavasiliou J, Tabakova $\mathrm{T}$, Idakiev $\mathrm{V}$, Loannides $\mathrm{T}$. A comparative study of ceria-supported gold and copper oxide catalysts for preferential CO oxidation reaction. Chem. Eng. J. $2006 ; 124(1-3): 41-5$.

4. Tamaki J, Shimanoe K, Yamada Y, Yamamoto $Y$, Miura $N$, Yamazoe $N$. Dilute hydrogen sulfide sensing properties of $\mathrm{CuO}-\mathrm{SnO} 2$ thin film prepared by low-pressure evaporation method. Sens. Actuators. B. 1998;49(1-2):121-5. 
5. $\quad \mathrm{Yu} \mathrm{Y}$, Zhang J. Solution phase synthesis of rose like CuO. Mater. Lett. 2009;63(21):1840-3.

6. Sundaramurthy N, Parthiban C. Biosynthesis of copper oxide nanoparticles using pyrus pyrifolia leaf extract and evolve the catalytic activity. IRJET. $2015 ; 2(6): 332-8$.

7. Michael JJ, Iniyan S. Performance analysis of a copper sheet laminated photovoltaic thermal collector using copper oxide - water nanofluid. J. Sol. Energy. 2015; 119:439-51.

8. Abboud Y, Saffaj T, Chagraoui A, El Bouari A, Brouzi K, Tanane $O$, Ihssane B. Biosynthesis, characterization and antimicrobial activity of copper oxide nanoparticles (CONPs) produced using brown alga extract (Bifurcaria bifurcata). Appl. Nanosci. 2014;4(5):571-6.

9. Gnanavel V, Palanichamy V, Roopan SM. Biosynthesis and characterization of copper oxide nanoparticles and ist anticancer activity on human colon cancer cell lines (HCT-116). J. Photoc. Photobio.B. 2017;171:133-8.

10. Wu SH, Chen DH. Synthesis of highconcentration $\mathrm{Cu}$ nanoparticles in aqueous CTAB solutions. J. Colloid. Interface. Sci. 2004;273(1):1659.

11. Wang $\mathrm{H}, \mathrm{Xu} \mathrm{JZ,} \mathrm{Zhu} \mathrm{JJ,} \mathrm{Chen} \mathrm{HY.} \mathrm{Preparation}$ of $\mathrm{CuO}$ nanoparticles by microwave irradiation. J. Cryst. Growth. 2002; 244:88-94.

12. Xu CK, Liu YK, Xu GD, Wang GH. Preparation and characterization of $\mathrm{CuO}$ nanorods by thermal decomposition of CuC2O4 precursor. Mater. Res. Bull. 2002;38(21):2365-72.

13. Anastas P and Warner J. Green chemistry: Theory and practice. Oxford University Press, USA; 1998.

14. Schmidt K. Woodrow Wilson International Center for Scholars and The Pew Charitable Trusts. In American Chemical Society Meeting, Washington DC, 2006.

15. Mittal AK, Chisti $\mathrm{Y}$ and Banerjee UC. Synthesis of metallic nanoparticles using plant extracts. Biotechnol. Adv. 2013;31(2):346-56.

16. Shah M, Fawcett D, Sharma S, Tripath SK and Poinern GEJ. Green Synthesis of Metallic Nanoparticles via Biological Entities. Materials. 2015;8(11):7278-308.

17. Nasrollahzadeh $M$, Maham M, Sajadi SM. Green synthesis of $\mathrm{CuO}$ nanoparticles by aqueous extract of Gundelia tournefortii and evaluation oftheir catalytic activity for the synthesis of $\mathrm{N}$ monosubstituted ureas andreduction of 4-nitrophenol. J. Colloid Interface Sci. 2015; 455:245-53.
18. Sreeju N, Rufus A, Philip D. Studies on catalytic degradation of organic pollutants and antibacterial property using biosynthesized $\mathrm{CuO}$ nanostructures. J. Mol. Liq. 2017; 242:690-700.

19. Mohan S, Singh Y, Verna DK, Hassan SH. Synthesis of $\mathrm{CuO}$ nanoparticles through green route using Citrus limon juice and its application as nanosorbentfor $\mathrm{Cr}(\mathrm{VI})$ remediation: process optimization with RSM and ANN-GA basedmodel. Process Saf. Environ. 2015; 96:156-66.

20. Naika HR, Lingarajua K, Manjunath K, Kumar D, Nagaraju G, Sureshd D, Nagabhushana H. Green synthesis of $\mathrm{CuO}$ nanoparticles using Gloriosa superba L. extract and their antibacterial activity. J. Taibah. Univ. Sci. 2015; 9:7-12.

21. Kumar V, Yadav SK. Plant-mediated synthesis of silver and gold nanoparticles and their applications. J. Chem. Technol. Biotechnol. 2009;84(2):151-7.

22. Akcin ÖE, Aktas T, Altıntas MY. Myosotis Alpestris F.W.Schmidt Boraaginaceae türünün anatomik özellikleri. Ordu Univ. J. Sci. Tech. 2013;3(1):61-8.

23. Nath I, Chakraborty J, Verpoort F. Environment, energy, emerging, applications, and sustainability. Elsevier, 2020.

24. Vidhu VK, Philip D. Catalytic degradation of organic dyes using biosynthesized silvernanoparticles. Micron.2014; 56: 54-62.

25. Sultan $M$, Javeed $A$, Uroos $M$, Imran $M$, Jubeen F, Nouren S, Saleem N, Bibi I, Masood R, Ahmed W. Linear and crosslinked polyurethanes based catalysts for reduction of methylene blue. J Hazard Mater. 2018; 344: 210-9.

26. Gahlaut A, Chhillar AK. Evaluation of antibacterial potential of plant extracts using resazurin based microtiter dilution assay. Int.J. Pharm.Pharm.Sci. 2013;5(2):372-6.

27. Sivaraj R, Rahman PKSM, Rajiv P, Salam HA, Venckatesh R. Biogenic copper oxide nanoparticles synthesis using Tabernaemontana divaricate leaf extract and its antibacterial activity against urinary tract pathogen. Spectrochim. Acta A. 2014; 133:17881.

28. Erci F, Koc RC and Isildak I. Green synthesis of silver nanoparticles using Thymbra spicata L. var. Spicata zahter aqueous leaf extract and evaluation of their morphology-dependent antibacterial and cytotoxic activity. Artif. Cells. Nanomed. Biotechnol. $2018 ; 46(1): 150-8$.

29. Bordbar M, Sharifi-Zarchi Z, Khodadadi B. Green synthesis of copper oxide nanoparticles/clinoptilolite using Rheum palmatum L. root extract: high catalytic activity for reduction of 4 - 
Doğan Çalhan S. Gündoğan M. JOTCSA. 2020; 7(2): 561-570.

nitro phenol, rhodamine B, and methylene blue. J Sol- 30. Das D, Nath BC, Phukon P, Dolui SK. Gel Sci Technol. 2017; 81:724-33.

Synthesis and evaluation of antioxidant and antibacterial behavior of $\mathrm{CuO}$ nanoparticles. Colloid Surface B. 2013; 101:430- 3. 